\title{
Salt and drought stress exhibits oxidative stress and modulated protein patterns in roots and leaves of date palm (Phoenix dactylifera L.)
}

\author{
Hussein J. SHAREEF ${ }^{1,2}$, Jameel M. AL-KHAYRI ${ }^{3}$
}

Salt and drought stress exhibits oxidative stress and modulated protein patterns in roots and leaves of date palm (Phoenix dactylifera L.)

Abstract: The formation of new proteins under the influence of harsh environmental conditions is a plant adaptation reaction. Two-year-old date palm tissue culture-derived plants from 'Barhee' grown in the field were subjected to salt stress $\left(70 \mathrm{~g} \mathrm{l}^{-1} \mathrm{NaCl}\right.$ ) and dehydration-induced by applying $70 \mathrm{~g} \mathrm{l}^{-1}$ polyethylene glycol or without irrigation and withholding irrigation $\left(0 \mathrm{~g} \mathrm{l}^{-1}\right)$ for one month. The soluble carbohydrate content increased in response to salinity and polyethylene glycol treatment in leaves compared to the control and drought treatment without irrigation. Proline increased in all treatments. Malondialdehyde and hydrogen peroxide increased under salinity. Salinity treatment increased the activity of ascorbate peroxidase and catalase enzyme. Salinity and polyethylene glycol treatments increased abscisic acid, whereas the indoleacetic acid level decreased. The protein pattern of roots and leaves in one-dimensional polyacrylamide gel electrophoresis showed that the stress conditions led to new protein bands' appearance and other proteins' disappearance. A comparison of protein patterns between the control and stress treatments revealed that the relative intensity of proteins in roots and leaves were more associated with salinity treatment than the drought. The results may be clearing important the molecular mechanism of tolerance under the influence of extreme environmental stress.

Key words: abscisic acid; ascorbate peroxidase; lipid peroxidation; malondialdehyde; polypeptide

Received August 13, 2020; accepted January 20, 2021. Delo je prispelo 13. avgusta 2020, sprejeto 20. januarja 2021.
Solni in sušni stres se izražata kot oksidacijski stres in vplivata na vzorce beljakovin $\mathrm{v}$ koreninah in listih dateljeve palme (Phoenix dactylifera L.)

Izvleček: Tvorba novih beljakovin je pod vplivom neugodnih okoljskih razmer prilagoditveni odziv rastlin. Dvoletne dateljeve palme, vzgojene v tkivnih kulturah iz sorte 'Barhee, posajene na prostem, so bile izpostavljene solnemu stresu $\left(70 \mathrm{~g} \mathrm{l}^{-1} \mathrm{NaCl}\right)$ in dehidraciji $\mathrm{z}$ uporabo $70 \mathrm{~g} \mathrm{l}^{-1}$ polietilen glikola ali brez zalivanja za en mesec $\left(0 \mathrm{~g} \mathrm{l}^{-1}\right)$. Vsebnost topnih ogljikovih hidratov se je v listih povečala kot odziv na slanost in obravnavanje s polietilen glikolom $\mathrm{v}$ primerjavi s kontrolo in obravnavanjem s sušo brez zalivanja. Vsebnost prolina se je povečala $\mathrm{v}$ vseh obravnavanjih. Vsebnosti malondialdehida in vodikovega peroksida sta se povečali v razmerah slanosti. Obravnavanje s slanostjo je povečalo aktivnosti encimov askorbat peroksidaze in katalaze. Obravnavanji s slanostjo in polietilen glikolom sta povečali vsebnost abscizinske kisline, a zmanšali vsebnost indolocetne kisline. Vorec beljakovin v koreninah in listih določen $\mathrm{z}$ enodimenzionalno poliakrilamidno gelsko elektroforezo je pokazal, da so stresne razmere vodile k novemu vzorcu beljakovin $\mathrm{v}$ stresnih razmerah in izginjanju drugih. Primerjava vzorcev beljakovin med kontrolo in stresnimi obravnavanji je pokazala, da je relativna jakost pojavljanja beljakovin v koreninah in listih bolj povezana z obravnavanjem s slanostjo kot s sušo. Rezultati bi lahko bili pomembni pri pojasnitvi molekularnega mehanizma tolerance pod vplivom ekstremnega okoljskega stresa.

Ključne besede: abscizinska kislina; askorbata peroksidaza; peroksidacija lipidov; malondialdehid; polipeptid

1 University of Basrah, Date Palm Research Center, Basrah, Iraq

2 Corresponding author, e-mail: husseinshareef@live.com

3 King Faisal University, College of Agriculture and Food Sciences, Department of Agricultural Biotechnology, Al-Ahsa, Saudi Arabia 


\section{INTRODUCTION}

Protein pattern analysis is a helpful instrument for testing plants' reactions to abiotic stress (Piasecka et al., 2019). Changes in natural conditions influence the quality and amount of plant proteins. Protein groups react significantly to ecological stress, for example, drought (Hellal et al., 2018)a laboratory experiment was conducted in a factorial randomized complete design with four replications. The controlled experiment included ten of Egyptian barley cultivars namely; (Giza 123, 124, 125, 126, 127, 129, 130, 134, 135 and 2000 and salt stress (Patankar et al., 2018)the molecular basis of this tolerance is complex and poorly understood. Therefore, this study aimed to identify the genes involved in salinity tolerance using a basic yeast functional bioassay. To achieve this, a date palm cDNA library was overexpressed in Saccharomyces cerevisiae cells. The expression levels of selected genes that make yeast cells tolerant to salt were subsequently validated in the leaf and root tissues of date palm seedlings using a quantitative PCR method. About 6000 yeast transformant cells were replica printed and screened on a synthetic minimal medium containing $1.0 \mathrm{M}$ of $\mathrm{NaCl}$. The screening results showed the presence of 62 salt-tolerant transformant colonies. Sequence analysis of the recombinant yeast plasmids revealed the presence of a group of genes with potential salt-tolerance functions, such as aquaporins (PIP. Salt stress is a major limiting factor in plant development and can lead to water stress (Elsheery et al., 2020; Shareef et al., 2020). Salinity reduces the plant's ability to absorb water (Naeem et al., 2013). Acosta-Motos et al. (2017) explained the mechanism of a direct effect of salinity on plants by triggering specific morphological, physiological, and biochemical changes. Determination of stress resistance involves useful molecules that induce adaptation reactions of the developing plant under stress conditions, such as specific proteins ( Ghatak et al., 2017; Mohamed et al., 2018).

The root is the vital organ that first experiences salt stress in the plant (Komatsu \& Hossain, 2013). Some proteins respond to salt stress induced in the roots more than other plant parts. The main proteins produced by salinity or drought stress are linked to carbohydrates and energy metabolism (Xu et al., 2015). Paul et al. (2015) stated that the main class of specific proteins resulting from stress ultimately leads to oxidative stress. These defense proteins accumulate in plant roots and play an initial role in plant endurance to drought (Omar et al., 2018).

A plant's tolerance to water stress or its avoidance depends on multiple mechanisms activated by different molecular signals in the roots, stimulated by abscisic acid such as SnRK2-interacting calcium sensor and AREB/ ABFs-ABRE-binding protein/ABRE-binding factor to send the message to the leaf to start the endurance mechanisms (Chae et al., 2007)we have isolated a dehydrationinducible gene (designated OSRK1. Abscisic acid represents the long-distance signal that moves from the roots to the leaves, increasing its concentration in the leaves due to expressing genes responsible for ABA biosynthesis, which leads to stomatal closure (Lokhande \& Suprasanna, 2012; De Smet \& Zhang, 2013).

Drought and salinity are essential environmental issues prevailing in date palm (Phoenix dactylifera L.) cultivation regions where they can negatively impact growth and productivity (Al-Khayri \& Al-Bahrany, 2004; Al-Bahrany \& Al-Khayri, 2012; Shareef, 2019). Several types of genetic markers have been used to characterize date palm varieties under different stress conditions based on phenotypic (Elsafy et al., 2015), biochemical (Yaish et al., 2015)little is known about the underlying molecular mechanisms that contribute to its salt tolerance. Only recently, investigators have uncovered microRNA-mediated post-transcriptional gene regulation, which is critical for typical plant development and adaptation to stress conditions such as salinity. To identify conserved and novel miRNAs in date palm and to characterize miRNAs that could play a role in salt tolerance, we have generated sRNA libraries from the leaves and roots of $\mathrm{NaCl}$-treated and untreated seedlings of date palm. Deep sequencing of these four sRNA libraries yielded approximately 251 million reads. The bioinformatics analysis has identified 153 homologs of conserved miRNAs, 89 miRNA variants, and 180 putative novel miRNAs in date palm. Expression profiles under salinity revealed differential regulation of some miRNAs in date palm. In leaves, 54 of the identified miRNAs were significantly affected and the majority (70\%, and molecular markers (Al Kharusi et al., 2017). Ponnaiah et al. (2019)crude protein (CP has shown that changes in the levels of proteins of pearl millet under salinity and drought conditions have helped to identify the genes involved in controlling tolerance to these stress conditions. In a previous experiment, El Rabey et al. (2015) used date palm seedlings to analyze proteomics for salinity and sensitive protein associated with water stress resulting from gene expression of salinity and dehydration in leaves. The current experiment aimed to analyze the protein pattern change and oxidative stress response in offshoots from tissue culture (true to type) date palms' leaves and roots exposed to drought and salinity.

\section{MATERIALS AND METHODS}

\subsection{PLANT MATERIAL AND STRESS CONDITIONS}

Two-year-old date palm plants 'Barhee' regenerated 
from tissue culture were used in this experiment, which was conducted at Alharthah, Basrah, Iraq $\left(30^{\circ} 38^{\prime} 47.1^{\prime \prime} \mathrm{N}\right.$ $\left.47^{\circ} 45^{\prime} 08.2^{\prime \prime} \mathrm{E}\right)$ during 2019. The plants were grown in silty clay loam soil with an organic fertilizer in September and expanded the offshoot cultivation area. On 1 October, the treatments were conducted. The minimum temperature was $18{ }^{\circ} \mathrm{C}$, the maximum $32^{\circ} \mathrm{C}$, the relative humidity was $30 \%$, and the light intensity $1350 \mu \mathrm{mol} \mathrm{m} \mathrm{m}^{-2}$. Five replicates of each treatment were investigated. The treatments consisted of regular irrigation, (control) withholding irrigation for one month, induced drought stress with field capacity was $12.5 \%$ (20 ml depth of water), induced drought stress using $70 \mathrm{~g} \mathrm{l}^{-1}$ polyethylene glycol (PEG), and salinity stress with $70 \mathrm{~g} \mathrm{l}^{-1}$ sodium chloride. Field capacity was $75 \%$ (120 ml depth of water) for PEG and salt treatment. After 30 days, samples were washed with distilled water, dry matter taken, whereas fresh samples frozen in liquid nitrogen.

\subsection{ESTIMATION OF TOTAL CARBOHYDRATE CONTENT}

The amount of total soluble sugar was estimated spectrophotometrically at $490 \mathrm{~nm}$ following the phenol sulfuric acid reagent method of Dubois et al. (1951). The leaves and roots $(100 \mathrm{mg})$ segments were homogenized in $80 \%$ ethanol and centrifuged at $2000 \mathrm{x}$ g for $25 \mathrm{~min}$. The supernatant $(1 \mathrm{ml})$ was mixed with $0.05 \%$ phenol $(2 \mathrm{ml})(\mathrm{pH} 6)$ and $98 \%$ sulfuric acid $(2 \mathrm{ml})$. The blends were hatched at 80 ${ }^{\circ} \mathrm{C}$ for $20 \mathrm{~min}$ in a water bath. Total soluble carbohydrate content was calculated using a standard curve of glucose and expressed as $\mathrm{mg} \mathrm{g}^{-1}$ F.M.

\subsection{DETERMINATION OF PROLINE}

Proline was extracted and estimated, according to Bates et al. (1973). Root and leaf (0.5 g dry matter) samples were homogenized separately in cold aqueous sulfosalicylic acid $3 \%(10 \mathrm{ml})$. The homogenate was sieved through Whatman No. 2 paper. In a test tube, $2 \mathrm{ml}$ of the filtrate was blended with acidic ninhydrin $(2 \mathrm{ml})$ and glacial acetic acid $(2 \mathrm{ml})$ and incubated in a $100{ }^{\circ} \mathrm{C}$ water bath for $1 \mathrm{hr}$. After quick cooling in an ice bath, toluene (4 ml) was included, and the mixture was shaken by hand. The toluene phase, containing the chromophore, was aspirated, and the absorbance of this phase, using samples of $1 \mathrm{ml}$, was determined at $520 \mathrm{~nm}$.

\subsection{MEASUREMENT OF LIPID PEROXIDATION}

Lipid peroxidation was determined by evaluating malondialdehyde (MDA). MDA was estimated dependent on the strategy of Esterbauer \& Cheeseman (1990). A blend of $0.6 \mathrm{~g}$ fresh plant tissue and TCA $5 \%$ (5 ml) was centrifuged at $12000 \mathrm{x}$ g for $25 \mathrm{~min}$. The supernatant was blended in thiobarbituric acid $0.67 \%(2 \mathrm{ml})$ and heated for $30 \mathrm{~min}$ at $100{ }^{\circ} \mathrm{C}$ in a water bath. Sample absorbance was evaluated at 450, 532, and $600 \mathrm{~nm}$ using a blank containing all reagents. MDA content of the sample was calculated using the formula:

$$
\mathrm{C}\left(\mu \mathrm{mol} \mathrm{g}{ }^{-1}\right)=6.45(\mathrm{~A} 532-\mathrm{A} 600)-0.56 \mathrm{~A} 450 \text {. }
$$

\subsection{ESTIMATION OF HYDROGEN PEROXIDE}

Leaves and roots $(500 \mathrm{mg}$ ) samples were crushed in trichloroacetic acid (TCA) $5 \%$, and the mixture was utilized for the assurance of $\mathrm{H}_{2} \mathrm{O}_{2}$ by the technique of Sagisaka (1976). The response blend with $50 \%$ of TCA, $10 \mathrm{mmol}$ ammonium sulfate ferrous, $2.6 \mathrm{~mol}$ potassium thiocyanide, and plant separate, the $480 \mathrm{~nm}$ used to read absorbance.

\subsection{EXTRACTION OF ANTIOXIDANT ENZYMES}

Leaves and roots (200 $\mathrm{mg}$ ) samples were absorbed in fluid nitrogen and crushed in an extraction buffer $(2.0 \mathrm{ml})$ : $100 \mathrm{mmol}$ potassium phosphate ( $\mathrm{pH} 7.8$ ), $0.1 \mathrm{mmol}$ ethylene diamine tetraacetic acid (EDTA), and $10 \mathrm{mmol}$ ascorbic acid. $13000 \mathrm{xg}$ for $15 \mathrm{~min}$ at $4{ }^{\circ} \mathrm{C}$ used to centrifuged the mixture. The catalase activity (CAT) and ascorbate peroxidase (APX) was measured by collecting the supernatant. All proteins were resolved with a similar support arrangement. Also, the evaluation was made utilizing the Bradford (1976) strategy. CAT activity determined by the technique depicted by Azevedo (1998) was utilized with specific alterations. Its operation was checked by a spectrophotometer assessing the $\mathrm{H}_{2} \mathrm{O}_{2}$ at $240 \mathrm{~nm}$ for $2 \mathrm{~min}$ in a response medium containing $100 \mathrm{mmol}$ potassium phosphate buffer ( $\mathrm{pH} 7.0$ ), $12.5 \mathrm{mmol} \mathrm{H}_{2} \mathrm{O}_{2}$, and $50 \mu \mathrm{l}$ of plant separate incubated at $28{ }^{\circ} \mathrm{C}$. As a new solution, a similar response medium free of separate was utilized. The activity of APX was resolved following Nakano \& Asada (1981) by observing the ascorbate's oxidation pace at $290 \mathrm{~nm}$. The response medium was incubated at $28{ }^{\circ} \mathrm{C}$. It was comprised of $100 \mathrm{mmol}$ potassium phosphate buffer $(\mathrm{pH} 7.0)$, $0.5 \mathrm{mmol}$ ascorbic acid, and $0.1 \mathrm{mmol} \mathrm{H}_{2} \mathrm{O}_{2}$. The reduction in absorbance was observed for $2 \mathrm{~min}$ from the beginning of the response.

\subsection{HORMONES ANALYSIS}

Five grams of a fresh tissue sample, which was homog- 
enized in $70 \%$ methanol, was stirred overnight at $4{ }^{\circ} \mathrm{C}$. The extract was filtered through Whatman filter paper (No.1) and evaporated under a vacuum. The $\mathrm{pH}$ of the aqueous phase was adjusted to 8.5 , using $0.1 \mathrm{~mol}$ phosphate buffer. Later the aqueous phase was partitioned twice using methanol. A rotary evaporator removed the methanol phase. The aqueous phase $\mathrm{pH}$ was adjusted to 2.5 , using $1 \mathrm{~N}$ hydrochloric acid $(\mathrm{HCl})$. The injection of the concentrate determined phytohormones into a reversedphase HPLC, C18 column in an isocratic elution mode utilizing a portable stage comprising of acetone: water (26:74) with $30 \mathrm{mmol}$ phosphoric acid as per Tang et al. (2011). The $\mathrm{pH}$ was kept up at 4, utilizing $1 \mathrm{~N}$ sodium hydroxide. The temperature was kept at $25^{\circ} \mathrm{C}$. The flux rate was $0.8 \mathrm{ml} \mathrm{min}{ }^{-1}$, and the elution of the phytohormones was observed at 208 and $265 \mathrm{~nm}$ for indoleacetic acid and abscisic acid, respectively.

\subsection{EXTRACTION OF PROTEINS AND GEL ELEC- TROPHORESIS}

Proteins were extracted by homogenizing the $300 \mathrm{mg}$ of solidified dried leaf in $1 \mathrm{ml}$ of extraction buffer $[0.2 \mathrm{~mol}$, tris-hydroxymethyl aminomethane (Tris) +0.001 mol ethylenediamine tetra acetic acid $+\left(\mathrm{Na}_{2}+\right.$ EDTA $+12 \%$ glycerol + $0.01 \mathrm{M}$ dithiothreitol (DTT) + $0.05 \mathrm{mmol}$ phenylmethylsulfonyl fluoride (PMSF)] and homogenized by a mortar and pestle. At that point, the samples were centrifuged at $15,000 \times \mathrm{g}$ for $15 \mathrm{~min}$; the buffer consisted of $0.125 \mathrm{M}$ Tris $\mathrm{HCl}(\mathrm{pH} 6.8)+4 \%$ SDS $+20 \%$, glycerol $+10 \%$ b-mercaptoethanol $+0.01 \%$ bromophenol blue. Protein samples were denaturized by heat in the water bath at $90{ }^{\circ} \mathrm{C}$ for $3 \mathrm{~min}$. Protein electrophoresis was performed in SDS polyacrylamide gel following procedures described by Laemmli (1970). The protein bands demonstrated clear changes, which were investigated by ImageJ programming.

\subsection{STATISTICAL DESIGN AND ANALYSIS}

The experiment was conducted according to the completely randomized blocks design for four treatments: control, drought, polyethylene glycol, salinity, with five replications per treatment. The mean values \pm the standard error were displayed. The data were subjected to analysis of variance (ANOVA) utilizing IBM (SPSS Statistics V23.0), and Duncan's multiple range test at $p<$ 0.05 were separated by the means.

\section{RESULTS}

\subsection{ANTIOXIDATIVE AND OXIDATIVE RE- SPONSE TO DROUGHT AND SALINITY STRESS}

Drought and salinity treatments altered soluble carbohydrate and proline in roots and leaves (Fig. 1a,b). Af-

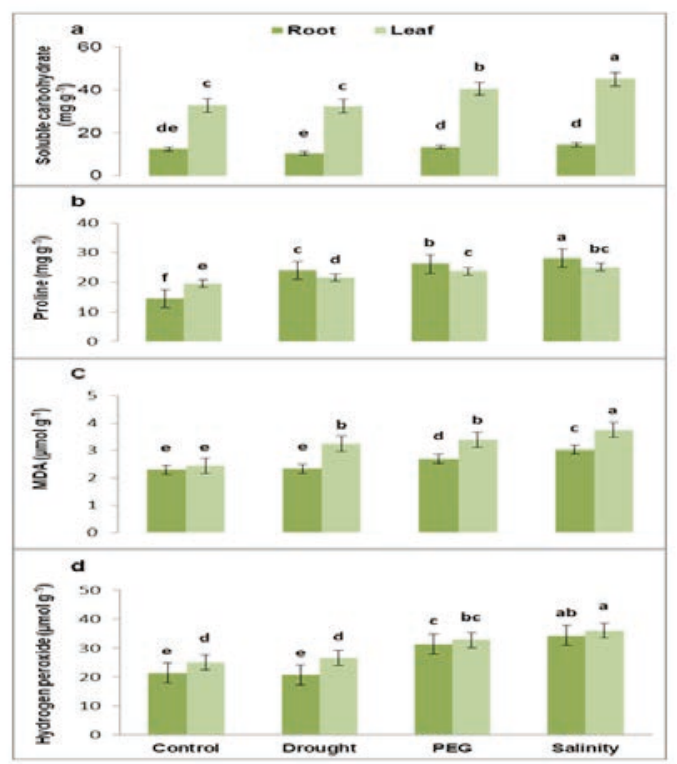

Figure 1: Oxidation change in response to drought, PEG and salinity stress, (a) Soluble carbohydrate, (b) Proline, (c) Malondialdehyde (MDA), (d) Hydrogen peroxide. Data are shown as means (of five replicates) \pm S.E. Different letters indicate significant differences between treatments of leaves and roots $(p<0.05)$ 
ter one month of treatment, the soluble carbohydrates' content increased significantly in response to salinity and PEG treatments in leaves related to the control and drought treatment. In contrast, without irrigation, the drought treatment decreased carbohydrates' content considerably in the roots (Fig. 1a).

Proline in leaves and roots increased significantly in all treatments related to the control (Fig. 1b). Salinity treatment increased MDA in leaves and roots related to the control (Fig. 1c). In contrast, drought treatment showed no significant difference in MDA compared to the control in roots. Salinity treatment increases the hydrogen peroxide in roots and leaves related to other treatments. In contrast, drought treatment had no significant difference in $\mathrm{H}_{2} \mathrm{O}_{2}$ related to the control in both roots and leaves (Fig. 1d).

\subsection{ENZYMES ACTIVITY AND HORMONAL LEVELS IN RESPONSE TO DROUGHT AND SALINITY STRESS}

Salinity treatment increased APX enzyme activity by 16.46 and $49.19 \%$ higher than the control in roots and leaves, respectively. At the same time, the drought treatment reduced APXenzyme activity by 20.81 and $15.65 \%$ compared to the control in roots and leaves, respectively (Fig. 2a). The CAT enzyme activity decreased significantly in response to drought in the roots and leaves related to the control. In contrast, the salinity treatment signifi- cantly increased CAT activity in leaves related to the control treatment (Fig. 2b).

Salinity and PEG treatments increased ABA's level in the leaves significantly by 47.86 and $216.02 \%$ compared to the control, respectively. Also, both the salinity and PEG treatments increased ABA's level significantly in the roots by 38.85 and $33.63 \%$ related to the control, respectively (Fig. 2 c). In the roots, the IAA level decreased significantly in response to salinity, $32.85 \%$ compared to the control. Whereas, in leaves, the IAA level decreased significantly in response to drought treatment, where $46.60 \%$ reduction was observed compared to the control (Fig. 2d).

\subsection{PROTEIN PATTERN CHANGES IN RESPONSE TO DROUGHT AND SALINITY STRESS}

The protein patterns of roots and leaves in onedimensional polyacrylamide gel electrophoresis (SDSPAGE) and subsequent examination by the ImageJ program demonstrated some striking contrasts (Fig. 3). The root protein patterns and relative intensity of protein expression showed that the appearance of protein bands 7 and 8 (molecular mass 59.492 and $37.410 \mathrm{kD}$, respectively) was up-managed by drought, while the expression of protein bands 4 and 5 (molecular mass 97.400 and $97.391 \mathrm{kD}$, respectively) was down-controlled under drought. The relative intensity of protein expression in protein bands 4,5 , and 7 was up-managed, while protein

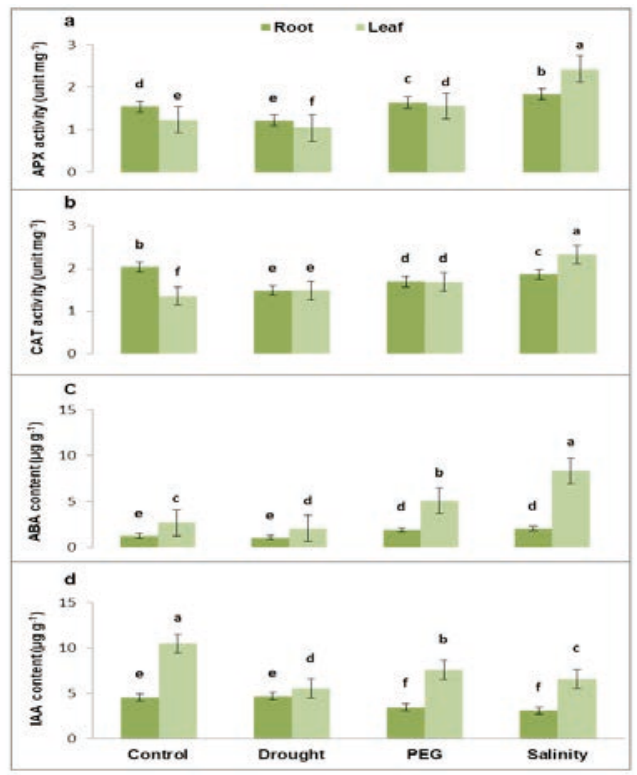

Figure 2: Enzymes activity and hormonal levels in response to drought, PEG and salinity stress, (a) Ascorbate peroxidase activity (APX), (b) Catalase activity (CAT), (c) Abscisic acid (ABA), (d) Indoleacetic acid (IAA). Data are shown as means (of five replicates) \pm S.E. Different letters indicate significant differences between treatments of leaves and roots $(p<0.05)$ 


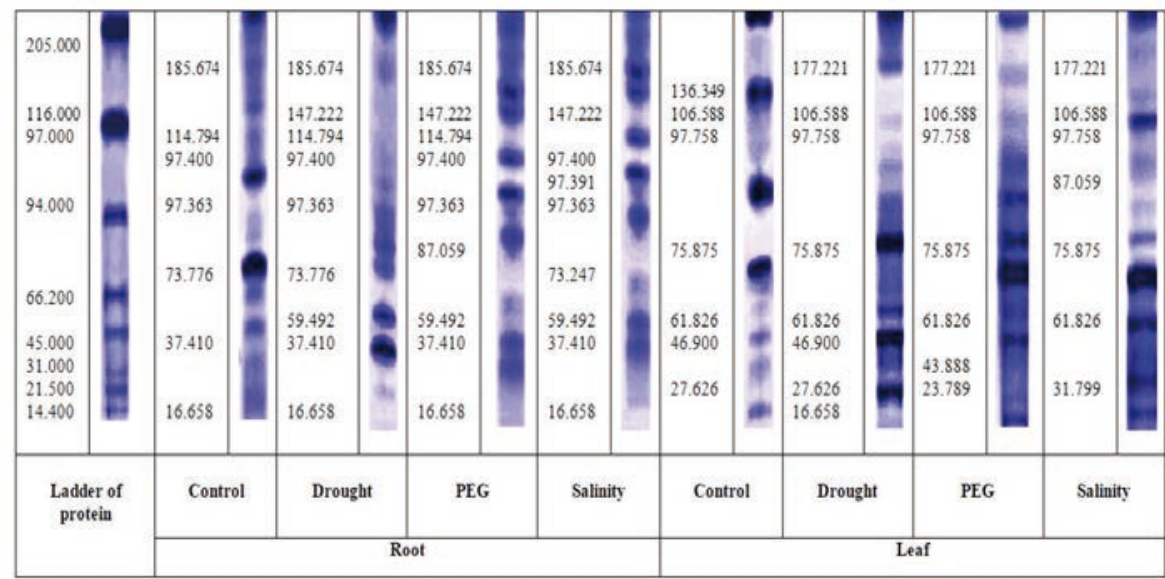

Figure 3: Analysis of protein patterns by one-D SDS-PAGE extracted from root and leaf, showing protein pattern changes in response to drought, PEG, and salinity stress

bands 1, 3, 8, and 9 (molecular mass 185.674, 114.794, 37.410 , and $16.658 \mathrm{kD}$, respectively) were down-controlled by PEG. The relative intensity of protein expression in protein bands 4,5 , and 7 was up-managed, while protein bands 1, 3, 8, and 9 (molecular mass 185.674, $114.794,37.410$, and $16.658 \mathrm{kD}$, respectively) were downcontrolled by PEG and salt stress except for protein band 3 which was not present in the salt stress treatment. The appearance of novel protein bands (including band 1 and 7 with molecular mass 147.222 and $59.492 \mathrm{kD}$, respectively) by drought, EPG, and salt stress related to the control, whereas band 6 (molecular mass $87.059 \mathrm{kD}$ ) was detected at PEG treatment and band 4 (molecular mass $97.391 \mathrm{kD}$ ) was found in the presence of salt stress treatment.

The leaf protein patterns and relative intensity of protein expression showed that the appearance of pro- tein band 2 (molecular mass of $106.588 \mathrm{kD}$ ) was up-managed by drought. In contrast, the expression of protein bands 3, 4, 5, 6, and 7 (molecular mass 97.758, 75.875, $61.825,46.900$, and $27.626 \mathrm{kD}$, respectively) was downcontrolled under drought. The relative intensity of protein expression in protein band 2 was up-managed, while protein bands 3, 4, and 5 were down-controlled by PEG. The relative intensity of protein expression in protein band 3 was up-managed, while protein bands 2,5 , and 6 were down-controlled by salt stress. The appearance of new protein bands, including band 1 with a molecular mass of $177.221 \mathrm{kD}$ by drought, EPG, and salt stress compared to the control.Whereas band 1 (molecular mass $136.349 \mathrm{kD}$ ) was not present in all treatments. The appearance of novel protein bands, including band 8 with a molecular mass of $16.658 \mathrm{kD}$, responded to drought. The protein bands 6 and 7 with a molecular mass of 43.888

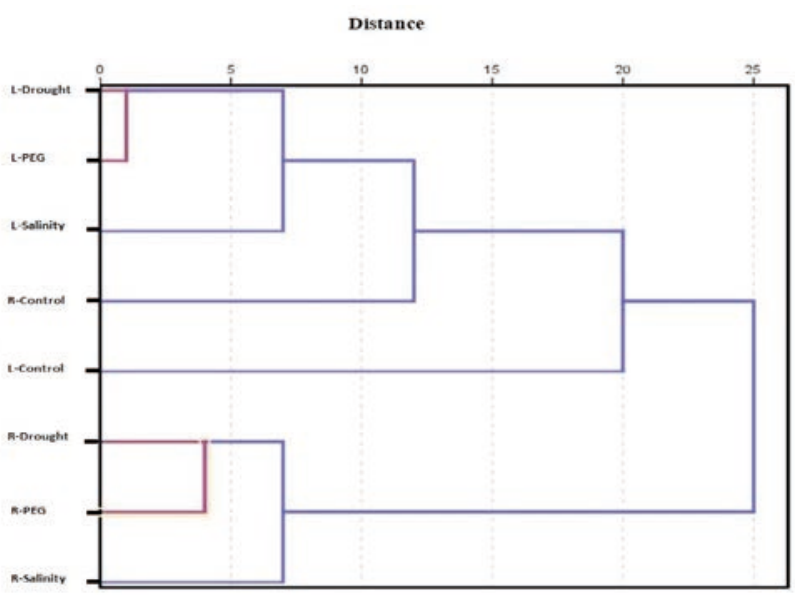

Figure 4: Dendrogram of hierarchical clustering to root (R) and the leaf (L) of date palm offshoot under drought, polyethylene glycol (PEG), and salinity stress by using protein patterns 
and $23.789 \mathrm{kD}$ responded to EPG. Also, bands 4 and 7 (with molecular mass 87.059 and $31.799 \mathrm{kD}$, respectively) appearance by salt stress (Fig. 3). Comparing the protein pattern in the control and all stress treatments revealed that the relative intensity in roots and leaves was associated more with salinity treatment than other tested factors.

\subsection{CLUSTER ANALYSIS OF PROTEIN PATTERN TO ROOT AND LEAF IN RESPONSE TO DROUGHT AND SALINITY STRESS}

Hierarchical cluster analysis of the protein pattern to root and leaf in response to drought and salinity stress (Fig. 4) showed two distinct clusters. The first group included drought, PEG, salinity, and control treatments to leaf (L-drought, L-PEG, L-Salinity, L-Control) and root control (R-Control). A significant similarity was observed between the drought treatments (L-drought) and PEG (L-PEG) in the leaf's protein pattern. At the same time, the second group included drought, PEG, and salinity treatments (R-Drought, R-PEG, R-Salinity), which showed the similarity between the treatments drought and PEG in the protein pattern of the root.

\section{DISCUSSION}

Salt and water stress are among the most severe environmental stress factors determining plant growth and development (Elsheery \& Cao, 2008). The relationship between new proteins and tolerance to extreme environmental conditions is essential for environmental stress research. Drought and salinity treatments alter soluble carbohydrates' and proline concentration in roots and leaves (Fig. 1). Soluble carbohydrates contribute to osmotic adjustment during stress and protect giant molecules and membranes' structure during extreme environmental conditions (De Lacerda et al., 2005; Helaly et al., 2018). Carbohydrates play an essential role as an antioxidant resulting from plant tissue damage (Al Hassan et al., 2015). Soluble carbohydrates contribute to IAA building, especially glucose, which increases the IAA primers, such as (ANT and TRP) (Sairanen et al., 2013). The root is known to be a sink organ of carbohydrates. The carbohydrates are reduced under drought treatment (Fig. 1a). Decreased polysaccharides' content in the root under the influence of dehydration results from sugars' consumption in the process of respiration (Jaleel et al. 2009).

Proline concentration in leaves and roots increased significantly in all treatments than the control (Fig. 1b). Proline increases in plants that are more tolerant to harsh environmental conditions. One of the most important adaptations to the surrounding conditions is the accumulation of proline under the influence of drought or salt stress (Amini \& Ehsanpour, 2005). Proline has a vital role in protecting the plant, promoting growth, and effective antioxidants in water stress conditions on the date palm (Dhawi \& Al-Khayri 2008; Butt et al. 2020). Also, proline helps protein inversion and a regular signal that activates multiple planting adaptation responses to extreme environmental conditions (Khedr et al., 2003). Increasing the proline concentration provides for protein building because it is an amino acid and improves endurance by maintaining cell water potential, osmotic balance, and membrane stability by preventing leaching.

Salinity treatment resulted in a significant increase in MDA and $\mathrm{H} 2 \mathrm{O} 2$ in leaves and roots (Fig. $1 \mathrm{c}, \mathrm{d}$ ). The high MDA and $\mathrm{H} 2 \mathrm{O} 2$ content shows increased oxidative stress and reflect tissue damage due to environmental stress (Ben Abdallah et al., 2017). The accumulation of sodium and chloride causes plant tissue damage, thus activating oxidative stress (Baghalian et al., 2008). MDA modifies many proteins into the photosynthetic center II (PSII) to stimulate the plant to adapt to environmental stress (Chen et al., 2018). Proteins are significant focuses for radicals and two-electron oxidants in biological systems because of their plenitude and high rate constants for the response (Davies, 2016). Hydrogen peroxide's most essential property is the capacity to cross cell membranes freely, which superoxide generally cannot do (Kurutas, 2016). High-level $\mathrm{H} 2 \mathrm{O} 2$ can stimulate new enzymatic proteins such as APX and CAT enzymes that scavenge free radicals (Sofo et al., 2015).

Salinity treatment increased APX and CAT activity in leaves and roots (Fig. 2 a,b). APX activity increased under saline stress conditions due to gene expression that contributes to the maintenance of enzyme activity and physiological processes ( Omar et al., 2012; Khan et al., 2020b). Gene expression of the enzyme is regulated during plant development responds to environmental stress (Huseynova et al., 2013). The effectiveness of APX directly contributes to the protection of plants against extreme environmental conditions (Khan et al., 2020a). Also, the APX enzyme's high activity can reduce the damage of reactive oxygen species (ROS) in the roots and thus increase the conversion of ROS to $\mathrm{H} 2 \mathrm{O} 2$ and the use of the enzyme to maintain root cells (Huang et al., 2019).

Dehydration leads to reduced growth in general and thus affects gene expression resulting in reduced synthesis of enzymes. Different enzyme activity under various stress factors confirms the validity of the antioxidant system (Khan et al., 2019). The high activity of the CAT enzyme in the leaves is attributed to the stability of the tolerance of environmental conditions in plants (Kawa- 
mura \& Muraoka, 2018). Reduced enzyme activity under drought stress compared to the standard conditions showed the role of $\mathrm{H} 2 \mathrm{O} 2$ as a signal transmitted from the root to the leaf and thus reduced the concentration of $\mathrm{H} 2 \mathrm{O} 2$ in the roots (Fig. 1d).

Salinity and PEG treatments increased ABA levels in the leaves and roots (Fig. 2c). The ABA signaling pathway receives and transmits hormonal stimulation to activate several events towards the plant's ability to adapt to environmental conditions (Vishwakarma et al., 2017). ABA signaling pathway affects building many proteins that lead to plant adaptation to extreme environmental conditions (Mittler \& Blumwald, 2015). The accumulation of ROS contributes to collecting the ABA required to activate the gene expression process (Vishwakarma et al., 2017).

Salinity and drought treatments decreased the level of IAA in the leaves and roots (Fig. 2d). IAA is involved in stimulating the construction of proteins such as $\mathrm{H+-}$ ATP (Salehin et al., 2019). Environmental stress modifies IAA transmission and its placement in the roots, so the auxin concentrations in the roots decrease when the plant is exposed to stress (Tanimoto, 2005). The reduction of IAA in the roots and leaves due to the imbalance in the growth regulators and the enzymes' inhibition is responsible for building auxin.

Comparing protein patterns in the control and stress treatments revealed that the relative intensity in roots and leaves was more significantly associated with salinity treatment than other factors (Figs. 3,4). Cluster analysis showed the convergence of the effect of PEG and drought stress on protein patterns, whether in leaf or root, while distinguishing the impact on drought and salinity. Plant growth and adaptation to environmental conditions are strongly influenced by protein metabolism (Ghatak et al., 2017). Various investigations have indicated that the construction of new proteins is associated with changes in plant environmental conditions such as salinity (Yaish et al., 2015) drought (El Rabey et al., 2015), which causes an increase or decrease in polypeptides. The results indicate that the environmental conditions of stress led to the emergence of new proteins and other proteins' disappearance, accompanied by unmatched stress proteins' appearance. The formation of new proteins under dehydration's influence refers to creating these proteins earlier on cell death programming as we observed shrinkage and stiffness in plants prone to dehydration.

\section{CONCLUSION}

One of the most challenging difficulties in recent literature related to plant endurance is to explain the mo- lecular basis of adaptation to environmental stress factors. A change in gene expression by drought stress leads to a cascade of changes, including the protein patterns. Exposure of date palm offshoots to dehydration creates specialized proteins whose primary function is to close the conveying channels in roots, close stomata, shrink cells, reduce vital processes, and maintain water in the tissues critical to maintaining plant survival. Exposure the plant to salinity builds multiple specialized proteins that improve the tolerance mechanism by modifying the roots' selective channels, closing the stomata, and activating the defense mechanism against oxidative stress.

\section{ACKNOWLEDGMENT}

The authors are grateful to Prof. Dennis V. Johnson of Cincinnati, Ohio, USA, for this manuscript's critical review and editorial enhancement.

\section{REFERENCES}

Acosta-Motos, J.R., Ortuño, M.F., \& Bernal-Vicente, A. (2017). Plant responses to salt stress: adaptive mechanisms. Agronomy, (7), 18. https://doi.org/10.3390/agronomy7010018

Al-Bahrany, A.M., \& Al-Khayri, J.M. (2012). In vitro responses of date palm cell suspensions under osmotic stress induced by sodium, potassium, and calcium salts at different exposure durations. American Journal of Plant Physiology,7(3), 120-134. http://dx.doi.org/10.3923/ajpp.2012.120.134

Al Hassan, M., Martínez Fuertes, M., Ramos Sánchez, F. J., Vicente, O., \& Boscaiu, M. (2015). Effects of salt and water stress on plant growth and on accumulation of osmolytes and antioxidant compounds in cherry tomato. Notulae Botanicae Horti Agrobotanici Cluj-Napoca, 43(1), 1-11. https://doi.org/10.15835/nbha4319793

Al Kharusi, L. A., Assaha, D. V. M., Al-Yahyai, R., \&Yaish, M. W. (2017). Screening of date palm (Phoenix dactylifera L.) cultivars for salinity tolerance. Forests, $8(4), 136$. https://doi. org/10.3390/f8040136

Amini, F., \& Ehsanpour, A. A. (2005). Soluble Proteins, Proline, Carbohydrates and $\mathrm{Na}+/ \mathrm{K}+$ Changes in Two Tomato (Lycopersicon esculentum Mill.) Cultivars under in vitro Salt Stress. American Journal of Biochemistry and Biotechnology, 1(4), 212-216. https://doi.org/10.3844/ajbbsp.2005.212.216

Azevedo, R.A., Alas, R.M., Smith, R.J. (1998). Responses of antioxidant enzymes to transfer from elevated carbon dioxide to air and ozone fumigation, in the leaves androots of wild type and catalase-deficient mutant of barley. Physiologia Plantarum, 104, 280-292. https://doi.org/10.1034/j.13993054.1998.1040217.x

Baghalian, K., Haghiry, A., Naghavi, M. R., \& Mohammadi, A. (2008). Effect of saline irrigation water on agronomical and phytochemical characters of chamomile (Matricaria recu- 
tita L.). Scientia Horticulturae, 116(4), 437-441. https://doi. org/10.1016/j.scienta.2008.02.014

Bates, L., Waldren, S., R. P. Teare, \& Rapid, I. D. (1973). Determination of free proline for water stress studies. Plant Soil, 39, 205-207. https://doi.org/10.1007/BF00018060

Ben Abdallah, M., Methenni, K., Nouairi, I., Zarrouk, M., \& Youssef, N. Ben. (2017). Drought priming improves subsequent more severe drought in a drought-sensitive cultivar of olive cv. Chétoui. Scientia Horticulturae, 221(September 2016), 43-52. https://doi.org/10.1016/j.scienta.2017.04.021

Bradford, M. M., Dong, Y. Y., Xu, L., Liu, S., \& Bai, X. (1976). A rapid and sensitive method for the quantitation of microgram quantities of protein utilizing the principle of proteindye binding. Analytical Biochemistry, 72(1-2), 248-254. https://doi.org/10.1016/0003-2697(76)90527-3

Chae, M. J., Lee, J. S., Nam, M. H., Cho, K., Hong, J. Y., Yi, S. A., Suh, S. C., \& Yoon, I. S. (2007). A rice dehydration-inducible SNF1-related protein kinase 2 phosphorylates an abscisic acid responsive element-binding factor and associates with ABA signaling. Plant Molecular Biology, 63(2), 151-169. https://doi.org/10.1007/s11103-006-9079-x

Chen, Z., Zhu, D., Wu, J., Cheng, Z., Yan, X., Deng, X., \& Yan, Y. (2018). Identification of differentially accumulated proteins involved in regulating independent and combined osmosis and cadmium stress response in Brachypodium seedling roots. Scientific Reports, 8(1), 1-17. https://doi.org/10.1038/ s41598-018-25959-8

Davies, M. J. (2016). Protein oxidation and peroxidation. Biochemical Journal, 473(7), 805-825. https://doi.org/10.1042/ BJ20151227

De Lacerda, C. F., Cambraia, J., Oliva, M. A., \& Ruiz, H. A. (2005). Changes in growth and in solute concentrations in sorghum leaves and roots during salt stress recovery. Environmental and Experimental Botany, 54(1), 69-76. https:// doi.org/10.1016/j.envexpbot.2004.06.004

De Smet, I., \& Zhang, H. (2013). Abscisic acid in root growth and development. In Plant Roots: The Hidden Half, Vol. 16. eds A. Eshel and T. Beeckman (Boca Raton: CRC Press), (pp. 1-13.).

Dhawi, F., \& Al-khayri, J. M. (2008). Proline Accumulation in Response to Magnetic Fields in Date Palm (Phoenix dactylifera L.). Agriculture, 2(1), 80-83. https://doi. org/10.2174/1874331500802010080

Dubois, M., Gilles, K.A., Hamilton, J. K., Rebers, P.A. \& Smith, F. (1951). Colourimetric determination of sugars and related substances. Analytical chemistry, 26, 351-356.

El Rabey, H. A., Al-Malki, A. L., \& Abulnaja, K. O. (2016). Proteome Analysis of Date Palm (Phoenix dactylifera L.) under Severe Drought and Salt Stress . International Journal of Genomics, 2016, 1-8. https://doi.org/10.1155/2016/7840759

Elsafy, M., Garkava-Gustavsson, L., \& Mujaju, C. (2015). Phenotypic Diversity of Date Palm Cultivars (Phoenix dactylifera L.) from Sudan Estimated by Vegetative and Fruit Characteristics . International Journal of Biodiversity, 2015(1), 1-7. https://doi.org/10.1155/2015/610391

Elsheery, N.I., \& Cao, C.F. (2008). Gas exchange, chlorophyll fluorescence, and osmotic adjustment in two mango cultivars under drought stress. Acta Physiologiae Plantarum, 30(6), 769-777. https://doi.org/10.1007/s11738-008-0179-x
Elsheery, N.I., Helaly, M.N., Omar, S.A., John, S.V.S., \& Zabochnicka-Swiątek, M. (2020). Physiological and molecular mechanisms of salinity tolerance in grafted cucumber. South African Journal of Botany, 130, 90-102. https://doi. org/10.1016/j.sajb.2019.12.014

Esterbauer, H.K. \& Cheeseman, H. (1990). Determination of aldehydic lipid peroxidation products: malonalde- hyde and 4-hydroxynonenal. Methods in Enzymology, 186. 407-421. https://doi.org/10.1016/0076-6879(90)86134-H

Ghatak, A., Chaturvedi, P., \& Weckwerth, W. (2017). Cereal Crop Proteomics: Systemic Analysis of Crop Drought Stress Responses Towards Marker-Assisted Selection Breeding. Frontiers in Plant Science, 8(June), 1-25. https:// doi.org/10.3389/fpls.2017.00757

Hellal, F. A., El-Shabrawi, H. M., Abd El-Hady, M., Khatab, I. A., El-Sayed, S. A. A., \& Abdelly, C. (2018). Influence of PEG induced drought stress on molecular and biochemical constituents and seedling growth of Egyptian barley cultivars. Journal of Genetic Engineering and Biotechnology, 16(1), 203-212. https://doi.org/10.1016/j.jgeb.2017.10.009

Helaly, M.N., El-Sheery, N.I., El-Hoseiny, H., Rastogi, A., \& Kalaji, H.M. (2018). Impact of treated wastewater and salicylic acid on physiological performance, malformation and yield of two mango cultivars. Scientia Horticulturae, 233, 159-177. https://doi.org/10.1016/j.scienta.2018.01.001

Huang, H., Ullah, F., Zhou, D. X., Yi, M., \& Zhao, Y. (2019). Mechanisms of ROS regulation of plant development and stress responses. Frontiers in Plant Science, 10(June), 1-10. https://doi.org/10.3389/fpls.2019.00800

Huseynova, I. M., Aliyeva, D. R., \& Aliyev, J. A. (2013). Plant responses to stresses: Role of ascorbate peroxidase in the antioxidant protection. Peroxidases: Biochemical Characteristics, Functions and Potential Applications, 4, 142-158.

Jaleel, C.A., P. Manivannan, A. Wahid, M., \& Farooq, R. S. (2009). Drought Stress in Plants: A Review on Morphological Characteristics and Pigments Composition. International Journal of Agriculture, 11, 100-105. https://doi. org/08-305/IGC-DYT/2009/11-1-100-105

Kawamura, T., \& Muraoka, I. (2018). Exercise-induced oxidative stress and the effects of antioxidant intake from a physiological viewpoint. Antioxidants, 7(9), 119; https:// doi.org/10.3390/antiox7090119

Khan, A., Khan, A. L., Imran, M., \& Shahzad, R. (2020a). Silicon and gibberellins: synergistic function in harnessing ABA signaling and heat stress tolerance in date palm (Phoenix dactylifera L.). Plants, 9(May), 620. https://doi.org/10.3390/ plants9050620

Khan, A., Khan, A. L., Muneer, S., Kim, Y. H., Al-Rawahi, A., \& Al-Harrasi, A. (2019). Silicon and salinity: Crosstalk in crop-mediated stress tolerance mechanisms. Frontiers in Plant Science, 10(October). https://doi.org/10.3389/ fpls.2019.01429

Khan, A., Numan, M., Khan, A. L., Lee, I. J., Imran, M., Asaf, S., \& Al-Harrasi, A. (2020b). Melatonin: Awakening the defense mechanisms during plant oxidative stress. Plants, 9(4). https://doi.org/10.3390/plants9040407

Khedr, A. H. A., Abbas, M. A., Abdel Wahid, A. A., Quick, W. P., \& Abogadallah, G. M. (2003). Proline induces the expression of salt-stress-responsive proteins and may improve the 
adaptation of Pancratium maritimum L. to salt-stress. Journal of Experimental Botany, 54(392), 2553-2562. https:// doi.org/10.1093/jxb/erg277

Komatsu, S., \& Hossain, Z. (2013). Organ-specific proteome analysis for identification of abiotic stress response mechanism in crop. Frontiers in Plant Science, 4(April), 1-9. https://doi.org/10.3389/fpls.2013.00071

Kurutas, E. B. (2016). The importance of antioxidants which play the role in cellular response against oxidative/nitrosative stress: Current state. Nutrition Journal, 15(1), 1-22. https://doi.org/10.1186/s12937-016-0186-5

Laemmli, U. (1970). Cleavage of structural proteins during the assembly of the head bacteriophage T4. Nature, 227, 680 685. https://doi.org/10.1038/227680a0

Mittler, R., \& Blumwald, E. (2015). The roles of ROS and ABA in systemic acquired acclimation. Plant Cell, 27(1), 64-70. https://doi.org/10.1105/tpc.114.133090

Naeem, M., Nasir Khan, M., A., M., Khan, \& Moinuddin, A. (2013). Adverse effects of abiotic stresses on medicinal and aromatic plants and their alleviation by calcium. In N. Tuteja \& S. Singh Gill (Eds.), Plant Acclimation to Environmental Stress (pp. 1-493). (C) Springer Science+Business Media New York. https://doi.org/10.1007/978-1-4614-5001-6

Nakano, Y., \& Asada, K. (1981). Hydrogen peroxide is scavenged by ascorbate-specific peroxidase in spinach chloroplasts. Plant Cell Physiology, 22(8), 67-80.

Omar, S.A., Elsheery, N.I., Elzaawely, A.A., Strobel, W., \& MKalaji, H. (2018). Over Expression of Jatropha's Dehydrin Jcdhn-2 Enhances Tolerance to Water Stress in Rice Plants. International Journal of Biosciences, 13(2), 53-60.

Omar, S.A., Elsheery, N.I., Kalaji, H.M., Xu, Z.F. Song-Quan, S., Carpentier, R., (2012). Dehydroascorbate reductase and glutathione reductase play an important role in scavenging hydrogen peroxide during natural and artificial dehydration of Jatropha curcas seeds. Journal of Plant Biology, 55(6), 469-480. https://doi.org/10.1007/s12374-012-0276-7

Patankar, H. V., Al-Harrasi, I., Al-Yahyai, R., \& Yaish, M. W. (2018). Identification of candidate genes involved in the salt tolerance of date palm (Phoenix dactylifera L.) Based on a yeast functional bioassay. DNA and Cell Biology, 37(6), 524-534. https://doi.org/10.1089/dna.2018.4159

Paul, S., Gayen, D., Datta, S. K., \& Datta, K. (2015). Dissecting root proteome of transgenic rice cultivars unravels metabolic alterations and accumulation of novel stress responsive proteins under drought stress. Plant Science, 234, 133-143. https://doi.org/10.1016/j.plantsci.2015.02.006

Piasecka, A., Kachlicki, P., \& Stobiecki, M. (2019). Analytical methods for detection of plant metabolomes changes in response to biotic and abiotic stresses. International Journal of Molecular Sciences, 20(2). https://doi.org/10.3390/ ijms20020379

Ponnaiah, G., Gupta, S. K., Blümmel, M., Marappa, M., Pichaikannu, S., Das, R. R., \& Rathore, A. (2019). Utilization of molecular marker based genetic diversity patterns in hybrid parents to develop better forage quality multi-cut hybrids in Pearl Millet. Agriculture (Switzerland), 9(5), 97. https://doi.org/10.3390/agriculture9050097

Sagisaka S. (1976). The occurrence of peroxide in a perennial plant Populas gelrica. Plant Physiology, 57, 308-309. https:// doi.org/10.1104/pp.57.2.308

Sairanen, I., Novák, O., Pěnčík, A., Ikeda, Y., Jones, B., Sandberg, G., \& Ljung, K. (2013). Soluble carbohydrates regulate auxin biosynthesis via PIF proteins in arabidopsis. Plant Cell, 24(12), 4907-4916. https://doi.org/10.1105/tpc.112.104794

Salehin, M., Li, B., Tang, M., Katz, E., Song, L., Ecker, J. R., Kliebenstein, D., \& Estelle, M. (2019). Auxin-sensitive Aux/ IAA proteins mediate drought tolerance in Arabidopsis by regulating glucosinolate levels. The preprint server for biology, 572305. https://doi.org/10.1101/572305

Shareef, H. J. (2019). Salicylic acid and Potassium Promote Flowering through modulating the hormonal levels and Protein pattern of Date palm Phoenix dactylifera L. Sayer offshoots. Acta Agriculturae Slovenica, 114(2), 231-238. https://doi.org/10.14720/aas.2019.114.2.8

Shareef, H. J., Abdi, G., \& Fahad, S. (2020). Change in photosynthetic pigments of Date palm offshoots under abiotic stress factors. Folia oecologica, 47(1), 45-51. https://doi. org/10.2478/foecol-2020-0006

Sofo, A., Scopa, A., Nuzzaci, M., \& Vitti, A. (2015). Ascorbate Peroxidase and Catalase Activities and Their Genetic Regulation in Plants Subjected to Drought and Salinity Stresses. International Journal of Molecular Sciences, 16, 1356113578. https://doi.org/10.3390/ijms160613561

Tang, Y., Wang, L., Ma, C., Liu, J., Liu, B., \& Li, H. (2011). The Use of HPLC in Determination of Endogenous Hormones in Anthers of Bitter Melon. Journal of Life Sciences, 5, 139142.

Tanimoto, E. (2005). Regulation of root growth by plant hormones - Roles for auxin and gibberellin. Critical Reviews in Plant Sciences, 24(4), 249-265. https://doi. org/10.1080/07352680500196108

Vishwakarma, K., Upadhyay, N., Kumar, N., Yadav, G., Singh, J., Mishra, R. K., Kumar, V., Verma, R., Upadhyay, R. G., Pandey, M., \& Sharma, S. (2017). Abscisic Acid Signaling and Abiotic Stress Tolerance in Plants: A Review on Current Knowledge and Future Prospects. Frontiers in Plant Science, 08(February), 1-12. https://doi.org/10.3389/ fpls.2017.00161

Xu, W., Cui, K., Xu, A., \& Nie, L. (2015). Drought stress condition increases root to shoot ratio via alteration of carbohydrate partitioning and enzymatic activity in rice seedlings. Acta Physiologiae Plantarum, 37:9. https://doi.org/10.1007/ s11738-014-1760-0

Yaish, M. W., Sunkar, R., Zheng, Y., Ji, B., Al-Yahyai, R., \& Farooq, S. A. (2015). A genome-wide identification of the miRNAome in response to salinity stress in date palm (Phoenix dactylifera L.). Frontiers in Plant Science, 6(NOVEMBER), 946. https://doi.org/10.3389/fpls.2015.00946 